Ks. Józef Grzywaczewski ${ }^{1}$

\title{
Święty Józef jako opiekun Jezusa i małżonek Maryi według Orygenesa
}

Rok świętego Józefa (2018) stworzył okazję do modlitw, pielgrzymek, a także studiów nad tą wyjątkową postacią poprzez konferencje, sympozja oraz publikacje o charakterze duszpasterskim i teologicznym. Swięty Józef i jego rola są powszechnie znane na podstawie Ewangelii, chociaż informacje na jego temat są skromne. Pisarze wczesnochrześcijańscy pisali o nim w kontekście chrystologicznym i mariologicznym, najczęściej nawiązywali do niego wtedy, gdy komentowali te fragmenty Ewangelii, gdzie jest mowa o jego roli w stosunku do Maryi i Dzieciątka Jezus. Antologia Textes patristiques sur saint Joseph opracowana w 12 częściach przez Guy-Marie Bertranda i C.-S. Pontona znajduje się w periodyku Cahiers de Josephologie ${ }^{2}$ (1955-1962 oraz 1968). Ogólna prezentacja nauki Kościoła na temat św. Józefa (Saint Joseph époux de Marie) opracowana przez Pierre'a Grelota, G.M. Bertranda i Aimé Soulignaca znajduje się

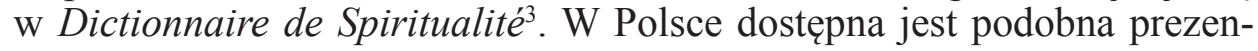

1 Ks. prof. dr hab. Józef Grzywaczewski, profesor zwyczajny w Katedrze Teologii Życia Duchowego w Instytucie Teologii Systematycznej na Wydziale Teologicznym UKSW, e-mail :j.grivalles@gmail.com, ORCID: 0000-0003-4464-5145.

2 Zob. Cahiers de Josephologie 3 (1955) z. 1, 141-168; 4 (1956) z.1, 149-174; 4 (1956) z. 2, 325-367; 5 (1957) z. 1, 125-162; 5 (1957) z. 2, 289-320; 6 (1958) z. 1, 149$179 ; 6$ (1958) z. 2, 265-321; 7 (1959) z. 1, 151-172; 7 (1959) z. 2, 275-321; 8 (1960) z. $1,171-186 ; 8$ (1960) z. 2, 348-374; 9 (1961) z. 2, 333-357; 10 (1962) z. 1, 149-182; 16 (1968) z. 2, 365-393.

3 Por. P. Grelot, Saint Joseph époux de Marie. Écriture, DSAM VIII 1289-1301; G.M. Bertrand, Saint Joseph époux de Marie. Patristique et haut Moyen Age, DSAM VIII 1301-1308; R. Gauthier, Saint Joseph époux de Marie. L'histoire de la spiritualité, DSAM VIII 1308-1316; R. Gauthier, Saint Joseph époux de Marie. Liturgie et documents pontificaux, DSAM VIII 1316-1321; A. Solignac, Saint Joseph époux de Marie. Le culte de saint Joseph aujourd'hui, DSAM VIII 1321-1323. 
tacja autorstwa ks. Tomasza Kaczmarka Święty Józef w nauczaniu Ojców Kościoła. Idee przewodnie ${ }^{4}$.

U wcześniejszych pisarzy, jak Justyn $(+167)$, Ireneusz $(+202)$ czy Orygenes (+254), wzmianki o św. Józefie są raczej skromne, u późniejszych autorów greckich, jak Efrem Syryjczyk (+ 373), Cyryl Aleksandryjski (+ 444), Jan Chryzostom (+ 407) czy Sofroniusz (VII wiek) znajdujemy bardziej pogłębioną myśl teologiczną, podobnie u autorów łacińskich, jak Hieronim (+419), Augustyn $(+430)$ czy Piotr Chryzolog $(+450)$. Świętym Józefem interesowali się autorzy apokryfów ${ }^{5}$, jednakże jemu wprost poświęcony jest tylko jeden apokryf i dotyczy on ostatnich lat życia Józefa ${ }^{6}$. Pogańscy pisarze greccy i łacińscy początkowo nie interesowali się religią chrześcijańską - być może jej nie dostrzegali lub uważali, że jest to jakaś grupa, która działa w ramach judaizmu. Później wszakże, szczególnie od czasu Nerona i wielkiego ataku na chrześcijan w roku 64, prześladowania wybuchały co parę lat (wszakże nie wszędzie jednocześnie) i pojawili się pisarze, którzy starali się ośmieszać wiarę chrześcijańską przez różnego rodzaju pamflety.

Znamy pisma greckich autorów, jak Epiktet, Lukian, Porfiriusz czy Galen ${ }^{7}$. Na Zachodzie najstarszym znanym krytykiem chrześcijan był Fronton z Cyrty. Najwybitniejszym pisarzem w tym kręgu jest Celsus. Wydał on w języku greckim około 178 roku dzieło pod tytułem Słowo prawdy. Nie zachowało się ono do naszych czasów, gdyż chrześcijanie nie byli zainteresowani jego kopiowaniem i przechowywaniem, a wpływy pogańskie stopniowo wygasały. Jest to zapewne największe dzieło antychrześcijańskie, jakie kiedykolwiek wydano aż do naszych czasów. Można je określić jako „encyklopedia kłamstwa”, a jego autora uznać za mistrza w dziedzinie karykatury ${ }^{8}$. Znamy to dzieło w $90 \%$ z cytatów, jakie umieścił Orygenes w swoim dziele Przeciw Celsusowi wydanym około 245 roku.

4 Por. www.swietyjozef.kalisz.pl/BibliotekaSwJozefa/246.html (dostęp: 24.02.2019).

5 Por. przypisy 80 i 81.

6 Por. Historia Iosephi fabri lignarii, tł. T. Hergesel: Apokryfy Nowego Testamentu, t. I/2, red. M. Starowieyski, Warszawa 2003, 559-578. Zob. M. Starowieyski, Barwny świat apokryfów, Poznań 2015, 37.

7 Por. M. Starowieyski, Plotka, pogarda, oszczerstwo - pisarze chrześcijańscy o poganach, w: Pierwsi świadkowie, red. M. Starowieyski, BOK 10, Kraków 1998, 351-397.

8 Por. P. de Labriolle, La réaction païenne. Étude sur la polémique antichrétienne du $I^{e r}$ au $V^{E}$ siècle, Paris 1950, 117: „Les attaques de Celse sont brutales et violentes [...]. Aux yeux de Celse, le christianisme et une religion barbare, absurde, faite pour les gens sans culture". 
Jest ono dostępne w języku polskim ${ }^{9}$. W tej książce widzimy, jak ówczesne piśmiennictwo atakowało młody Kościół ${ }^{10}$, ale widzimy też, że chrześcijanie nie pozostawiali satyrycznych pism bez odpowiedzi i bronili swej wiary, posługując się słowem pisanym i publikowanym. W niniejszym artykule zajmiemy się przede wszystkim Orygenesem z uwagi na to, że pisał on o Maryi, o narodzeniu Jezusa i o świętym Jozefie w kontekście ataków na chrześcijaństwo ze strony pogan.

\section{Symboliczne znaczenie miasta Nazaret oraz imienia Józef}

Nie ma, jak dotąd, historycznego wyjaśnienia, dlaczego święta rodzina mieszkała w Nazarecie. Józef jako przynależny do rodu Dawida pochodził z Judei, jego miastem było Betlejem, dlatego tam udał się na spis ludności. Można przypuszczać, że Maryja także pochodziła z rodu Dawida i pochodziła z Judei, wszak Jej krewna Elżbieta mieszkała w rejonie Jerozolimy. W Ewangelii Łukasza powiedziane jest, że była to górska kraina w Judei (Łk 1,3). Zdaniem Marie Vidala powód zamieszkania w Nazarecie tkwi w nazwie tego miasta: po hebrajsku Notseret jest to rodzaj żeński, to słowo znaczy 'ta, która strzeże', w dalszym znaczeniu nazwa ta odnosi się do Boga, który strzeże swego ludu w miłości według zawartego przed wiekami Przymierza ${ }^{11}$. M. Vidal ukazuje Józefa, syna Jakuba, oblubieńca Maryi, który dopełnia tego, co symbolicznie i typologicznie rozpoczął Józef, syn patriarchy Jakuba (Rdz 37,1-49,28). Nie wydaje się wszakże, aby Józef i Maryja osiedlili się w Nazarecie ze względu na nazwę tego miasta.

Do Józefa Egipskiego nawiązuje także Orygenes, ale bierze pod uwagę przede wszystkim jego walory moralne: „Gdybyśmy na przykład założyli, że Józef mógł ulec pożądliwości i że popełnił grzech z żoną swego pana

9 Grecki tekst dzieła: Origenes Werke, P. Koetschau, Leipzig 1899. Jest też nowsze wydanie: Origène, Contre Celse, tł. M. Borret, SCh 132, 136, 147, 150, 227. Wydanie zrealizowano w latach 1967-1977. Posługujemy się tłumaczeniem: Orygenes, Przeciw Celsusowi, tł. S. Kalinkowski, Warszawa 1986.

10 Por. M. Fédou, Christianisme et religions païennes dans le Contre Celse d'Origène, Paris 1988, 42: „Celse tient que la religion instaurée par Jésus professe une doctrine sans valeur".

11 Por. M. Vidal, Un Juif nommé Jésus. Une lecture de l'Évangile à la lumière de Torah, Paris 2000, 149: „Parler de Nazareth (Notseret, celle qui garde) était pour eux (chrétiens) faire mémoire de leur responsabilité et du regard du Seigneur sur eux [...] comme si Lui-même s'émerveillait de l'Alliance". Zob. Vidal, Un Juif nommé Jésus, s. 151 . 
(Rdz 39,7), to nie sądzę, aby patriarchowie powiedzieli o nim jego ojcu: «Józef, twój syn, żyje» (Rdz 45,26). Bo gdyby to uczynił, z pewnością by nie żył. Wszak «dusza, która grzeszy, umrze» (Ez 10,4)"12. Prawość Józefa przyniosła konkretne owoce: „Pismo stwierdza: «Poszli z Egiptu w górę i przybyli do Chanaanu, do swego ojca Jakuba» (Rdz 45,25). Wówczas też mówią do ojca: «Józef, twój syn, żyje i jest władcą całej ziemi egipskiej» (Rdz 45,26)”13. To powiedziawszy, Orygenes wyjaśnia: „Otóż «dzierżyć władzę nad Egiptem» oznacza tyle co: podeptać żądzę zmysłową, unikać wyuzdania, zdusić i okiełznać wszystkie rozkosze cielesne"14. Postać Józefa, który może służyć za wzór w dziedzinie moralnej, ma - zdaniem Orygenesa - znaczenie typologiczne: „Kto powiada: «To dla mnie coś wielkiego, że Józef, mój syn, żyje» (Rdz 45,27), tak jakby rozumiał i wiedział, że wielkie jest życie, które tkwi w duchowym Józefie"15. Według Orygenesa wszystko, o czym jest mowa w Starym Testamencie, zapowiada, co miało się w pełni ukazać w Nowym Testamencie. Kim jest zatem ów duchowy Józef? Orygenes odpowiada, że „prawdziwy Józef [to] nasz Pan i Zbawiciel"'16. Również i Tertulian uważał, że Józef Egipski jest symbolem (typem) Chrystusa ${ }^{17}$.

Jak widać, teolog aleksandryjski odnosi dzieła Józefa Egipskiego do Jezusa Chrystusa, nie wspomina w tym kontekście o Józefie z Nazaretu, którego życie jest wszakże mocno związane z osobą Zbawiciela. Można zatem powiedzieć, że Józef jako opiekun Jezusa częściowo uczestniczy w Jego misji, a jako syn Izraela znajduje się w przejściu od Starego do Nowego Testamentu. Orygenes nie był odosobniony w swych poglądach. Również św. Ambroży (+397) odnosił postać Józefa Egipskiego bezpośrednio do Chrystusa ${ }^{18}$.

Samo imię Józef (Jehoseph) pochodzi od Jo ('Jeho, Jahwe') oraz jasaj ('dodać'). To imię znaczy 'niech Bóg doda (dobra lub błogosławieństwa)' ${ }^{19}$.

12 Origenes, Homilia in Genesim 15, 2, t1. S. Kalinkowski: Orygenes, Homilie o Księgach Rodzaju, Wyjścia, Kapłańskiej, PSP 31/1, Warszawa 1984, 139.

13 Origenes, Homilia in Genesim 15, 1 (PSP 31/1, 139).

14 Origenes, Homilia in Genesim, 15, 3 (PSP 31/1, 141).

15 Origenes, Homilia in Genesim, 15, 3 (PSP 31/1, 140-141).

16 Origenes, Homilia in Genesim, 15, 7 (PSP 31/1, 146).

17 Por. Tertullianus, Adversus Marcionem III 18: „Joseph et ipse Christus figuratus, nec hoc solo, ne demorer cursum, quod persecutionem a fratribus passus est ob Dei gratiam sicut et Christus a Judaeis carnaliter fratribus".

18 Por. Ambrosius, Expositio Evangelii secundum Lucam IX 5, 57.

19 Por. H. Fros - F. Sowa, Twoje imię. Przewodnik onomastyczno-hagiograficzny, Kraków 1975, 263. 


\section{Wątpliwości Józefa jako pretekst do satyry}

Niektórzy ludzie, tak pochodzenia żydowskiego, jak i pogańskiego, próbowali za wszelką cenę zdyskredytować religię chrześcijańską, ukazując jej wyznawców jako naiwnych głupców, a także usiłowali w karykaturze przedstawić poszczególne postacie z Nowego Testamentu, poczynając od Jezusa i Maryi. Dziewicze poczęcie stanowiło dość łatwy wątek, gdyż zamiast podejmować próbę zrozumienia nauki chrześcijańskiej na ten temat, łatwiej było powiedzieć, że cała ta historia jest po prostu przykrywką do niewierności małżeńskiej Maryi. Takie pogłoski utrwalił na piśmie cytowany powyżej Celsus.

W pewnym stopniu inspirację do posądzenia Maryi o brak wierności w stosunku do Józefa mógł stanowić zapis w Ewangelii: „Mąż Jej Józef, który był człowiekiem prawym i nie chciał jej narazić na zniesławienie, zamierzał oddalić Ją potajemnie" (Mt 1,19). Wiele osób uważało, że to zdanie należy rozumieć w tym sensie, jakoby Józef zauważył, iż Maryja była w stanie oczekiwania na potomstwo, a wiedział, że nie on jest tego przyczyną. W takim przypadku należało oskarżyć narzeczoną o niewierność i dać jej list rozwodowy ${ }^{20}$. Nie wydaje się wszakże, aby powodem wątpliwości Józefa były tego rodzaju podejrzenia. Ewangelia o tym nie mówi. Gdyby Józef zauważył odmieniony stan Maryi, to zauważyłyby to przede wszystkim kobiety z Jej otoczenia. A gdyby one cokolwiek zauważyły, to sprawa by się nie ukryła. Przede wszystkim nie jest powiedziane, że Józef postanowił opuścić Maryję, lecz tylko, że wziął taką myśl pod rozwagę ${ }^{21}$, czyli decyzji nie podjął. Zdaniem Papieża Benedykta XVI okre-

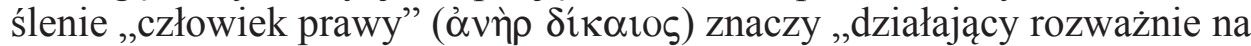
wzór postaci ze Starego Testamentu"22.

Było to w czasie, gdy Józef i Maryja jeszcze nie mieszkali razem, czyli w okresie pomiędzy zaślubinami (czyli zaręczynami) a uroczystością

20 Taką możliwość dopuszcza Stefan Szymik i wskazuje na swego rodzaju sprzeczność w postawie Józefa: jako człowiek prawy, czyli sprawiedliwy w pojęciu Starego Testamentu, miał obowiązek zerwać małżeństwo i oskarżyć Maryję o cudzołóstwo. Był jednak człowiekiem dobrym i litościwym, dlatego nie chciał wystawiać Jej na zniesławienie. Por. S. Szymik, Józef Oblubieniec, EK VIII 124.

21 A. Mello, Évangile selon saint Matthieu, tł. A. Chevillon, Paris 1999, 66 : „Joseph n'a jamais pensé un seul instant à écrire un acte de répudiation pour son épouse".

22 Por. Benedykt XVI, Jezus z Nazaretu. Dzieciństwo, tł. W. Szymona, Kraków 2012, 57: „Nazwanie Józefa sprawiedliwym (saddik) wychodzi daleko poza decyzję podjętą w tym momencie; ukazuje całościowy wizerunek św. Józefa i dołącza go jednocześnie do wielkich postaci Starego Testamentu". 
weselną 23. W Ewangelii Mateusza czytamy: „Po zaślubinach Matki Jego (Maryi) z Józefem, wpierw zanim zamieszkali razem" (Mt 1,18). Ponieważ akt zaręczynowy miał moc obowiązującą, narzeczonego można było określać jako mąża a narzeczoną jako żonę ${ }^{24}$. Jednocześnie kobieta, którą określano jako żona była dziewicą.

Jeśli ewangelista pisze, że Józef ,nie chciał narazić Maryi na zniesławienie i zamierzał oddalić Ją potajemnie", to ma na myśli nie tyle rozejście się, lecz raczej pomysł, aby Jej w ogóle nie przyjmować do swego domu. $\mathrm{W}$ powyżej przytoczonym zdaniu $\mathrm{w}$ języku greckim jest użyte słowo

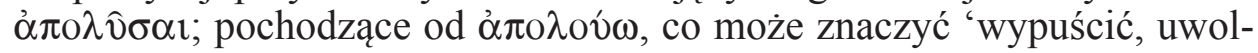
nić, rozwiązać (umowę)'. Termin ten był też używany w sensie 'rozejść się, oddalić żonę'. Ale do zerwania zawartego poprzednio kontraktu, jawnie czy potajemnie, potrzeba było mieć konkretny powód, a takiego Józef nie miał. Gdyby nic nie mówiąc, opuścił Nazaret, okazałby się człowiekiem niestatecznym i byłoby to zniesławienie dla Maryi i dla obu rodzin. Gdyby pozostał w Nazarecie, nie dopełniając małżeństwa i nie podając tego przyczyny, mieszkańcy miasta mieliby permanentny motyw do plotek i domysłów.

Niektórzy przypuszczają, że Józef nie miał zastrzeżeń co do niewinności Maryi ${ }^{25}$, lecz mógł zauważyć u Niej coś niezwykłego, coś, co wynikało z Jej niezwykłej łączności z Bogiem. Zapewne nie miał możliwości, aby o tym dyskutować z Maryją. Doświadczał lęku przed rzeczywistością niewidzialną, której na tym etapie rozumieć nie mógł. Pamiętamy, że także postacie ze Starego Testamentu często odczuwały lęk przed spotkaniem z Bogiem ${ }^{26}$. Widzenie anioła spowodowało lęk u kapłana Zachariasza (Łk

23 Por. J. Gnilka, Das Matthäusevangelium, Erster Teil, Herders theologischer Kommentar zum Neuen Testament, t. I/1, Freiburg - Basel - Wien 1986, 17: „Jako zaślubiona kobieta żyła jeszcze w domu rodziców pod patria potestas. Rok później następowało przyjęcie do domu, czyli zawarcie małżeństwa”. Cyt. za: Benedykt XVI, Jezus z Nazaretu. Dzieciństwo, s. 56.

24 Mello, Évangile, s. 65: „Le matrimonial droit juif distingue entre les fiançailles (erusin) et les noces (qiddushin ou «sanctification» du mariage), mais les fiançailles, comparativement au droit grec ou romain engagent un peu plus. Joseph, en effet, est déjà l'époux de Marie, et elle est son épouse : seul acte de divorce pouvait les libérer de leur promesse".

25 Por. M. Reboul, L'immaculée Conception, Clé de la voûte de la Création, Versailles 2018, 84: „Joseph voulait se réparer de Marie [...]. Il n'a jamais douté de la pureté de Marie, dont le regard était le plus lumineux que jamais, et de la fidélité à son veux de virginité".

26 Lęku doznał Izajasz, gdy miał widzenie Boga i zawołał: „Biada mi, jestem zgubiony [...], a oczy moje oglądały Króla, Jahwe Zastępów” (Iz 6,5-6). Izraelitom nie wolno było zbliżać się do Góry Synaj, gdzie odbywało się spotkanie Mojżesza z Bogiem (Wj 
1,12). Józef mógł więc lękać się zbliżenia do tajemnicy. Może czuł się niegodny takiego wyróżnienia. Można założyć, że Józef, doświadczając takich trudności, prosił Boga o pomoc i światło, gdyż tak zwykle postępują ludzie o głębokiej wierze ${ }^{27}$.

Pomoc w rozwiązaniu tego dylematu przyszła od Boga, ale w formie dość trudnej do przyjęcia. Według Ewangelii Mateusza „Anioł Pański ukazał mu się we śnie i rzekł: Józefie, synu Dawida, nie bój się wziąć do siebie Maryi, twej Małżonki, albowiem z Ducha Świętego jest to, co się w Niej poczęło" (Mt 1,30). Tak oto Józef otrzymał wezwanie, aby wziął Maryję do swego domu, jak to było przewidziane w akcie zaręczynowym. Czy od razu zrozumiał, co znaczy „,poczęła z Ducha Świętego"?28 Nie wiadomo. Jednakże zastosował się do otrzymanego polecenia, dopełnił przewidzianych formalności i gdy Dziecię się urodziło w Betlejem, można było mówić swobodnie: „Jezus, syn Józefa” (Jeszua ben Joseph). Orygenes, mając na myśli to wszystko, stwierdza: „Genealogia Chrystusa prowadzi od Dawida do Józefa [...], który nie był ojcem Zbawiciela, i żeby cała genealogia zachowała swój sens, nazwano go «ojcem» Pana"29.

Józef był po prostu potrzebny do tego, aby Jezus miał klarowną genealogię i mógł działać publicznie. Na innym miejscu Orygenes dodaje: „Józefa nazwano «mężem» [...] dlatego, aby niektórzy ludzie przypuszczali, iż Maryja poczęła za jego sprawą; chodziło o to, aby jej nie ukamienowano za to, iż utraciła dziewictwo" 30 . Orygenes podkreśla, że w Ewangelii Łukasza powiedziane jest, że „Jezus był, jak mniemano, synem Józefa” (Łk 3,23), a to znaczy, że nikt nie zgłaszał wątpliwości co do legalności Jego pochodzenia ${ }^{31}$.

19,12). Potem, jak Jakub ujrzał drabinę wstępu do nieba i aniołów Bożych, rzekł: „O jakże to miejsce przejmuje grozą! Prawdziwie to jest dom Boga i brama niebios" (Rdz 28,17). Uzza, sługa Dawida, który odważył się dotknąć Arki Przymierza, został ukarany śmiercią $(1 \mathrm{Krn} 13,10)$.

27 Mello, Évangile, s. 67: „Joseph est agité par beaucoup de pensées, mais il n’a pas encore trouvé une solution. Il est dans un état de recherche dans une attitude de prière".

28 Benedykt XVI, Jezus z Nazaretu, s. 60: „Czy możliwe jest, aby Bóg w taki sposób postępował z człowiekiem? [...] Możemy więc wyobrażać sobie, jaką wewnętrzną walkę prowadzi z tym niesłychanym orędziem otrzymanym we śnie: «Józefie, synu Dawida, nie bój się wziąć do siebie Maryi, twej Małżonki, albowiem z Ducha Świętego jest to, co się w Niej poczęło» (Mt 1,20)".

29 Origenes, In Lucam homiliae 17, 1, tł. S. Kalinkowski: Orygenes, Homilie o Ewangelii św. Łukasza, PSP 36, Warszawa 1986, 78.

30 Origenes, In Lucam homiliae, fragment 11 (20) (PSP 36, 150).

31 Por. Origenes, In Lucam homiliae 28, 3. 


\section{Satyryczna postać Pantery}

We wspomnianym dziele Contra Celsum Orygenes nie tylko komentuje legendę o jakimś Panterze, ale także podaje, skąd ona pochodzi. Pisze on: „Celsus wprowadza na scenę postać fikcyjnego Żyda, który w dyskusji z Jezusem stawia Mu szereg zarzutów infantylnych i nie licujących z powagą filozofa [...], a przede wszystkim ten, że Jezus «podaje się za syna dziewicy, podczas gdy w rzeczywistości urodził się w jakiejś zapadłej wsi żydowskiej jako syn miejscowej biednej wyrobnicy»" ${ }^{\prime 32}$. Stanisław Kalinkowski, tłumacz dzieła Contra Celsum na język polski, zaznacza, że Celsus „był człowiekiem wykształconym, erudyta czującym sie swobodnie na gruncie greckiej literatury i filozofii" ${ }^{33}$. Był on tradycyjnie przywiązany do pogaństwa, chociaż zapewne nie wierzył w mitologiczne opowiadania o bogach helleńskich. Posiadał on umysł krytyczny oraz wielkie zdolności satyryczne. Wydaje się, że jego księga zawiera sumę tego wszystkiego, co ówcześni poganie myśleli o chrześcijanach. Chcąc nadać wartości swojej książce, starał się zarzuty przeciw chrześcijanom oprzeć na rzekomo naukowych argumentach, a poszczególne zasady wiary poddać (pozornie) racjonalnej ocenie, aby wykazać ich niedorzeczność. Potrafił sięgać do pism helleńskich oraz sugestywnie je interpretować na swoją korzyść. Znał niezbyt dobrze księgi chrześcijańskie, lecz, jak się wydaje, nie wszystkie. By podważać ich treść, nie chciał opierać się tylko na swojej subiektywnej ocenie, lecz szukał oparcia wśród ludzi, którzy jakoby doskonale znali początki chrześcijaństwa. Założył, że takimi są przede wszystkim osoby pochodzące z Izraela, a takich było wielu w Aleksandrii, podobnie zresztą jak w innych miastach. Wydaje się, że ów fikcyjny Żyd, którego wprowadził do swej książki, przedstawiał to wszystko, czego Celsus mógł się dowiedzieć od swoich rozmówców pochodzenia żydowskiego ${ }^{34}$. Opieranie się na tego rodzaju świadkach miało nadawać wartości jego rzekomo naukowym, a rzeczywistości satyrycznym wywodom.

Tenże Żyd, traktowany jako znawca chrześcijaństwa, twierdził, że mąż Maryi, cieśla, „wypędził ją, gdy dowiódł jej cudzołóstwa, a ona wygna-

32 Origenes, Contra Celsum I 28, tł. S. Kalinkowski: Orygenes, Przeciw Celsusowi, Warszawa 1986, 55.

33 S. Kalinkowski, Wstęp, w: Orygenes, Przeciw Celsusowi, tł. S. Kalinkowski, Warszawa 1986, 17.

34 Por. R.L. Fox, Païens et chrétiens. La religion et la vie religieuse dans l'Empire Romain de la mort de Commode au Concile de Nicée, tł. R. Almi - M. Montabrut - E. Pailler, Toulouse 1997, 500: ,[...] attaque du païen Celse envers le christianisme. Dans les années 170, son ouvrage mettait en avant un juif dont les vues sur le christianisme étaient très proches des attaques des juifs contre le nouveau Messie". 
na przez męża i zhańbiona tułała się po świecie, aż potajemnie urodziła Jezusa" 35 . Tego rodzaju stwierdzenie, nawet oparte na świadectwie z kręgów żydowskich, nie wydawało się Celsusowi wystarczająco przekonujące, gdyż było ono zbyt ogólne. Uznał za konieczne wprowadzenie bliższych danych na ten temat. Orygenes pisze:

Powróćmy jednak do słów fikcyjnego Żyda, który twierdzi, że „matka Jezusa została wypędzona przez swego męża, cieślę, pod zarzutem cudzołóstwa, gdy była brzemienna po stosunku z żołnierzem, niejakim Panterą". Zastanówmy się, czy autorzy tej bajki o cudzołóstwie Dziewicy z Panterą i o cieśli, który ją wypędził, nie wymyślili jej wyłącznie po to, aby móc odrzucić fakt poczęcia Jezusa przez Ducha Świętego ${ }^{36}$.

Tak sformułowana plotka brzmi znacznie poważniej; chodzi nie tylko o jakąś pogłoskę na temat Maryi, ale pojawia się konkretne imię tego, z kim miała do czynienia. Sprawę pogarsza to, iż Pantera był żołnierzem, czyli zapewne poganinem, a więc dziecko tak zrodzone nie tylko nie miało normalnej rodziny, lecz jeszcze $\mathrm{w}$ dodatku było pochodzenia pogańskiego. W polskim wydaniu Contra Celsum w komentarzu do powyższego oszczerstwa podane jest, że ta historia znajduje się w Talmudzie, co oznacza, że zrodziła się ona w kręgu żydowskim ${ }^{37}$. Orygenes na wielu stronach stara się wykazać, że historia o Panterze jest kłamstwem i oszczerstwem. Tego rodzaju pogłoski znane były wśród chrześcijan nawet w VIII wieku, chociaż zapewne nie traktowano ich poważnie ${ }^{38}$. Stanisław Kalinkowski w komentarzu do Przeciw Celsusowi pisze: „O późnym pochodzeniu tego zarzutu może świadczyć fakt, że Jezus stanął przed Sanhedrynem, a przywilej ten zgodnie z Pwt 23,3 był zarezerwowany tylko dla ludzi o pochodzeniu bezspornie prawym" "39. Gdyby były jakiekolwiek wątpliwości co do pochodzenia Jezusa, to faryzeusze i uczeni w Piśmie by się nimi posłużyli, tymczasem nikt takich zarzutów nie zgłosił. Człowiek o pogańskim pochodzeniu nie mógłby zapewne wchodzić do świątyni ani do synagogi, a tym bardziej tam przemawiać. Legenda o Panterze powstała pod koniec I wieku, czyli około 50 lat po zmartwychwstaniu Chrystusa. Mogła ona wszakże stanowić chwytliwy wątek dla polemistów antychrześcijańskich w pierwszych wiekach Kościoła, a przenikała także do chrześcijan.

35 Origenes, Contra Celsum I 28 (Kalinkowski, 55).

36 Origenes, Contra Celsum I 32 (Kalinkowski, 57-58).

37 Por. Orygenes, Przeciw Celsusowi, s. 55, przyp. 90.

38 Por. Germanus, In sanctissimae Dei Genetricis Annuntiationem.

39 Orygenes, Przeciw Celsusowi, s. 58, przyp. 97. 
Niektórzy sądzą, że sam wyraz „Pantera” mógł się pojawić na skutek wadliwej wymowy wyrazu parthenos. Gdy mówiono Jesus hios Parthenou ('Jezus syn Dziewicy'), osoby mniej znające język grecki mogły słyszeć Jesus hios Pantherou, stąd pomysł, że ten wyraz w mianowniku może brzmieć Panter (Panther) albo Pantera. Niektórzy autorzy chrześcijańscy, chcąc wyjaśnić, skąd się wziął ten sztuczny wyraz, dopuszczali myśl, że mógł to być przydomek Jakuba, ojca św. Józefa ${ }^{40}$. To wszystko wskazuje, że satyryczna legenda o Panterze była dość popularna w starożytności, nawet jeśli nikt nie traktował jej poważnie ${ }^{41}$.

W takim kontekście to, co jest powiedziane w Ewangeliach o Józefie i jego roli, nabiera wyjątkowego znaczenia, nawet gdy informacje te są skromne.

\section{Wyjątkowa rola św. Józefa}

Wiadomości o św. Józefie znajdują się przede wszystkim w Ewangelii Dzieciństwa. Orygenes wydobywa je w swej polemice z Celsusem.

\subsection{Rola Józefa przed narodzeniem Jezusa}

Orygenes, odrzuciwszy plotki o Panterze, starał się wykazać, że sprawa poczęcia Jezusa przedstawia się tak, jak jest ukazana w Ewangeliach, a przy tym wspomina o Józefie. W swym dziele Przeciw Celsusowi pisał na temat satyryków żydowskich i pogańskich:

Było rzeczą zrozumiałą, że ci, którzy nie wierzą w cudowne poczęcie Jezusa, musieli w tym miejscu wymyślić jakieś kłamstwo. Wymyślili jednak historię nieprawdopodobną, a jednocześnie przyznali, iż Jezus począł się poza związkiem Dziewicy z Józefem. Każdy kto potrafi odróżnić prawdę od fałszu, łatwo dostrzeże w ich słowach kłamstwo [...]. Pytam więc Greków, a przede wszystkim Celsusa, który jest, a może nie jest platonikiem, ale powołuje się na Platona. Czy Bóg, który umieszcza dusze w ciałach ludzkich, obrałby drogę haniebnych i cudzołożnych urodzin, aby wprowadzić w sferę ludzkiego

40 Por. Orygenes, Przeciw Celsusowi, s. 57, przyp. 97.

${ }^{41}$ Wydaje się, że podobnie rozpowszechniła się w średniowieczu legenda o papieżycy Joannie. Była ona chętnie powtarzana, co nie znaczy, że traktowano ją poważnie. Por. A. Boureau, La papesse Jeanne, Paris 1988; C. Rustici, The Afterlife of Pope Jean: Developing of the Popess Legend in Early Modern England, Michigan 2006. 
życia Istotę, która miała podjąć się wielkiego zadania, która miała nauczać wielu ludzi i wyciągnąć ich z bagna grzechu ${ }^{42}$.

Orygenes stara się odpowiedzieć zarówno Żydom, jak i Grekom. Najpierw jednych i drugich chwyta za słowo: wprowadzając jakiegoś pogańskiego żołnierza do swej argumentacji, pośrednio przyznają oni, że Jezus nie został poczęty ze związku z Maryi z Józefem. Tak więc macierzyństwo Maryi jest oczywiste, nawet dla przeciwników chrześcijaństwa, a także to, że Józef nie jest ojcem Jezusa. Znając zamiłowanie Greków do filozofii, pyta: czyż Bóg, który wprowadza duszę do ciała ${ }^{43}$, mógłby wprowadzić na świat Jezusa drogą haniebnego związku? Na pewno nie. A zatem nie ma miejsca dla Pantery.

Należało dać też odpowiedź Żydom. Wiedząc o ich szacunku do Biblii, Orygenes sięga do proroctw mesjańskich:

Teraz, jak sądzę, jest stosowna pora, żeby słowom fikcyjnego Żyda przeciwstawić proroctwo Izajasza [...]. Słowa proroctwa brzmią: „Oto Dziewica pocznie i porodzi syna i nazwie Go imieniem Emanuel, to znaczy: Bóg z nami” (Iz 7,10-14). [...]. Gdyby Żyd upierał się i twierdził, że w zacytowanym fragmencie Pisma jest mowa o pannie, a nie o dziewicy, odpowiem mu, że hebrajski wyraz Aalma, który Septuaginta przekłada jako dziewica, a inni tłumaczą jako panna, znajduje się, jak wiadomo, w Księdze Powtórzonego Prawa i oznacza dziewicę ${ }^{44}$.

Myśl Orygenesa jest jasna: skoro Żydzi uznali, że Józef nie jest ojcem Jezusa, to zamiast rozpowiadać bajki o Panterze, powinni przyjąć proroc-

42 Origenes, Contra Celsum I 32 (Kalinkowski, 58).

43 Zdaje się, że Orygenes wyraża się na sposób chrześcijański: zapewne pamięta o Platońskiej teorii o wędrówce dusz, ale chyba nie uwzględnia poglądu, że są one wieczne, a zatem nie tyle Bóg (Demiurg) je wysyła do ciał, ile krążą one według jakiegoś odwiecznego prawa. Por. W. Tatarkiewicz, Historia filozofii, t. 1, Warszawa 1978, 91: „Platon był przekonany, że (dusza) nie tylko trwa dłużej od ciała, ale trwa wiecznie. Istnienie jej nie ma końca, a także nie ma początku, jest nie tylko nieśmiertelna, ale i odwieczna". G. Reale, Historia filozofii starożytnej, tł. E.I. Zieliński, t. 2, Lublin 1997, 221-241.

44 Origenes, Contra Celsum I 34 (Kalinkowski, 59). Por. Pwt 22,23-24: „Jeśli dziewica została zaręczona z mężem, a spotkał ją jakiś inny mężczyzna i spał a nią, oboje wyprowadzicie do bramy miasta i kamienować ich będziecie, aż umrą: dziewczynę za to, że nie krzyczała będąc w mieście, a mężczyznę za to, że zadał gwałt żonie bliźniego swego". Dla naszego tematu ważne jest, że ta sama kobieta określona jest raz jako panna, a raz jako żona. Pismo Święte bierze pod uwagę ewentualność wewnętrznej zgody kobiety na współżycie z obcym mężczyzną. Jeśli da się dowieść, że takiej zgody nie było, wówczas karę ponosi tylko mężczyzna. 
two Izajasza, interpretując je w sensie mesjańskim. Jeśli dziwi ich nadzwyczajne poczęcie Jezusa, to niech sobie uświadomią, że u Boga wszystko jest możliwe. Ważne jest to, że Orygenes w polemice stosuje się do greckiego i do żydowskiego sposobu myślenia ${ }^{45}$.

\subsection{Rola Józefa w ucieczce do Egiptu}

Józef, pokonawszy pierwszą trudność, zastosował się do pouczenia otrzymanego we śnie i wziął Maryję do siebie. Potem, jak wiadomo, udał się z Nią do Betlejem, aby się zapisać w księgi, stosownie do zarządzenia cesarza Augusta (Łk 2,1). Józef mógł pochodzić z Betlejem w Judei, gdyż należał do rodu Dawida. To miasto jest wymienione wprost $\mathrm{w}$ proroctwie Micheasza ${ }^{46}$. Z Żywotów cezarów Swetoniusza dowiadujemy się, że August „na całe życie przyjął dozór nad obyczajami i prawami. Z tego tytułu, chociaż bez godności cenzora, trzykrotnie przeprowadził przegląd ludności”" ${ }^{47}$. Orygenes nie miał wątpliwości, że spis ludności się rzeczywiście odbył i nadał temu wydarzeniu znaczenie teologiczne:

Ewangelisto, jaki pożytek przynosi mi opowiadanie o tym, że pierwszy spis całego świata (descriptio universi orbis) odbył się za panowania cesarza Augusta i że wraz ze wszystkimi również Józef ze swą brzemienną małżonką, Maryją, poddał się spisowi, a przed zakończeniem spisu urodził się Jezus? [...] koniecznym było, aby i Chrystus został zapisany na listę mieszkańców całego świata (orbis universi), aby zapisany razem ze wszystkimi, uświęcił wszystkich i wpisany do rejestru świata (relatus in censum) udzielił światu

45 Tę umiejętność dostrzegamy u św. Pawła: w dyskusjach z Żydami sięgał obficie do Starego Testamentu, a w przemowie na Areopagu nawiązał do posągów bożków oraz do poetów Kleantesa i Aratosa (por. Dz 17,28-30).

46 Por. Mi 5,1: „A ty, Betlejem Efrata, najmniejsze jesteś spośród plemion judzkich! $\mathrm{Z}$ ciebie mi wyjdzie Ten, który będzie władał w Izraelu, a pochodzenie Jego od początku od dni wieczności".

47 Caius Suetonius Tranquillus, De vita ceasarum II 27, tł. J. NiemirskaPliszczyńska: Gajus Swetoniusz Trankwillus, Żywoty cezarów, Wrocław 1987, 90. W komentarzu do tego fragmentu w polskim thumaczeniu (s. 123-124) powiedziane jest, że te spisy odbyły się w 28 oraz w 8 roku przed Chrystusem. Spis, o którym mówi Ewangelia, mógł być dokonany w Izraelu w ramach tego, który został nakazany w 8 roku przed Chrystusem. Być może w Izraelu to rozporządzenie zostało wykonane z opóźnieniem. Ok. roku 6/7 po Chrystusie odbył się kolejny spis ludności w Palestynie. Por. M. Simon - A. Benoît, Le Judaïsme et le Christianisme antique d'Antiochus Epiphan à Constanin, Paris 2006, 83. 
łączności ze sobą, aby po tym spisie wpisał wszystkich ludzi razem ze sobą do księgi żyjących (Ap 20, 15) ${ }^{48}$.

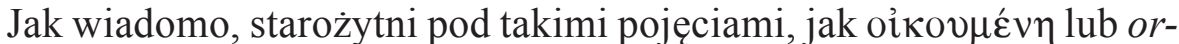
bis terre czy orbis universi rozumieli Cesarstwo Rzymskie, chociaż wiedzieli, że poza cesarstwem istnieją inne kraje. Pamiętamy, że król Herod, panujący jako wasal cesarza rzymskiego, „kazał pozabijać wszystkich chłopców w wieku do lat dwóch" (Mt 2,14) ${ }^{49}$. Zapewne taka zbrodnia mieściła się w ramach uprawnień władców satelickich krajów, z perspektywy Rzymu bowiem nie miało znaczenia to, że „barbarzyńcy”, jak mówiono wówczas, zabijają się pomiędzy sobą, zważano natomiast, aby nie atakowali ośrodków rzymskich. Był to okres, w którym Żydzi, na czele z Herodem, cieszyli się szczególnymi względami ze strony cesarzy rzymskich $^{50}$. Niezależnie od tego Herod mógł się wzorować na podobnym wydarzeniu w Rzymie: ktoś ogłosił jako proroctwo, że urodzi się przyszły król i wówczas ,senat wystraszony tą możliwością powziął uchwałe, że nie wolno utrzymać przy życiu żadnego chłopca w tym roku urodzonego" 51 . Gdy Herod podjął podobną decyzję dla regionu Betlejem, św. Józef po raz drugi otrzymał polecenie we śnie (Mt 2,13-15). Orygenes komentuje to wydarzenie w ten sposób: „Herod postanowił zabić Jezusa [...].Wszelako anioł, strzegąc porządku rzeczy, doradził Józefowi, aby wraz z Dzieckiem i Jego Matką udał się do Egiptu"52. Nieco dalej dodaje: „To, co zostało napisane, nie wydaje się niczym niezwykłym. W obydwu przytoczonych miejscach (por. Mt 1,20;2,13) jest bowiem mowa o tym, że anioł przemawiał do Józefa we śnie; a przecież często się zdarza, że ludzie we śnie otrzymują wskazówki, jak mają postapić" 53 . Tak mówiąc, Orygenes nie pomniejsza roli św. Józefa, lecz podkreśla rzeczywistość owego snu w tym sensie, że skoro tego typu pouczenia otrzymują różni ludzie, to dlaczego nie miałby ich otrzymać Józef? Powodem, dla któ-

48 Origenes, In Lucam homiliae 11, 6 (PSP 36, 61).

$49 \mathrm{Na}$ temat daty narodzenia Jezusa w Betlejem, por. J. Naumowicz, Narodziny Bożego Narodzenia, Kraków 2016, 17-30.

50 Por. R. Bartnicki, Dzieje głoszenia Słowa Bożego. Jezus i najstarszy Kościót, Kraków 2015, 20: „Gdy Cezar znalazł się w trudnej sytuacji w Egipcie, z pomocą pospieszyli mu Antypater - wówczas minister i prefekt pałacu - oraz Hirkan II, arcykapłan żydowski [...]. Przywileje Cezara potwierdzili następnie cesarze August i Tyberiusz".

51 Suetonius, De vita ceasarum II 94 (Pliszczyńska, 126). Z relacji Swetoniusza wynika, że to rozporządzenie nie zostało wykonane. W tym roku urodził się Oktawian August, który później został jedynowładcą Rzymu.

52 Origenes, Contra Celsum I 61 (Kalinkowski, 78).

53 Origenes, Contra Celsum I 66 (Kalinkowski, 83). 
rego Orygenes wspomina o śnie Józefa, są, jak zwykle, fałszywe opinie Celsusa:

Z Ewangelii Mateusza wydobywa Celsus opowiadanie o podróży Jezusa do Egiptu, jednak nie wierzy cudom, które tę podróż spowodowały, nie wierzy, że rozkaz udania się do Egiptu przekazał anioł [...]. Równocześnie próbuje szkalować [Jezusa] twierdząc, że [cuda] zostały dokonane sztuczkami magicznymi, a nie mocą Bożą; powiada, że wychowany potajemnie Jezus najął się do pracy w Egipcie i tam nauczył się określonych sztuk ${ }^{54}$.

To powiedziawszy, Orygenes wykazuje niedorzeczność opinii, jakoby Jezus był magiem. Tak więc akcent położony powyżej na nadprzyrodzony charakter poleceń danych Józefowi we śnie wyjaśnia w pełni powód ucieczki do Egiptu.

\subsection{Wiedza Jezusa, Maryi i Józefa}

Podczas gdy Celsus przejawia chorobliwą nienawiść do chrześcijan, Orygenes, odpierając jego wymysły, chętnie wykazuje jego ignorancję w sprawach wiary chrześcijańskiej oraz sprzeczności w jego wywodach. Pisze on: „Twierdzi z kolei Celsus, że Jezus, mówiąc o bogaczach: «Łatwiej jest wielbłądowi przejść przez ucho igielne niż bogatemu wejść do Królestwa niebieskiego» (Mt 19,24), zinterpretował następujące słowa Platona: «Wyróżniać się cnotą i bogactwem równocześnie nie jest możliwe» (Prawa 5, 12) $)^{55}$ ". To typowa metoda dla pogan: wyśmiewanie cudów Jezusa jako kuglarstwo oraz traktowanie trafnych sformułowań jako cytatów lub aluzji do greckiej filozofii bądź literatury. Wiele było ludzi, którzy uważali, że jeśli gdziekolwiek jest coś wartościowego, to na pewno pochodzi ono od Greków. Orygenes odpowiada na taki zarzut: „Któż, chrześcijanin czy poganin, nie wyśmieje Celsusa, usłyszawszy od niego, że Jezus, urodzony i wychowany wśród Żydów, uchodzący za syna cieśli Józefa, nieznający ani greckiego, ani hebrajskiego alfabetu, czytał księgi Platona" ${ }^{56}$. Tak oto postać Józefa jest przywołana na potwierdzenie tego, że nauka Jezusa z Nazaretu nie pochodzi z pism Platona (ani innych pisarzy helleńskich).

O tym, że Józef był cieślą, wiemy z Ewangelii (Mt 13,55). Wyraz „,cieśla" po grecku brzmi $\tau \dot{\varepsilon} \kappa \tau \omega \nu$, znaczy on 'stolarz, cieśla', nawet 'budowni-

\footnotetext{
54 Origenes, Contra Celsum I 38 (Kalinkowski, 62).

55 Origenes, Contra Celsum VI 16 (Kalinkowski, 298).

56 Origenes, Contra Celsum VI 16 (Kalinkowski, 298).
} 
czy', ogólnie mówiąc ‘człowiek pracujący w drzewie'. Tacy ludzie mogli być cenieni, jeśli dobrze wykonywali swą pracę, ale ich styl życia nie dawał możliwości odbywania studiów w jakiejkolwiek dziedzinie. Wszystko wskazuje na to, że Jezus żyjący w takim środowisku nie należał do sfery intelektualistów helleńskich. Mógł natomiast w dzieciństwie uczęszczać do szkoły synagogalnej, gdyż takie w wielu miejscowościach istniały ${ }^{57}$. Alberto Mello przypuszcza, że w Nazarecie nie było synagogi jako specjalnego budynku ${ }^{58}$, lecz tylko jakaś sala dla celów religijnych. Wydaje się, że w takich warunkach też można było prowadzić zajęcia dla dzieci.

Na pewno Jezus posiadał określoną wiedzę jako Syn Boży, ale mógł się posługiwać aramejskim tłumaczeniem Biblii, a możliwe, że i hebrajskim. James Martin pisze:

W Galilei nie każdy był piśmienny, ale Jezus był, skoro potrafił czytać Pisma. A biorąc pod uwagę, że Jego nauczanie jest przepojone myślą i językiem świętych tekstów judaizmu, należy przypuszczać, że formacja religijna, jaką otrzymał Jezus w rodzinie, była intensywna i głęboka i obejmowała naukę czytania w biblijnym (języku) hebrajskim [...]. Możemy więc przyjąć, że Jezus na co dzień posługiwał się aramejskim, znał hebrajski i być może mówił trochę po grecku ${ }^{59}$.

Z tą opinią można się zgodzić, niemniej, o ile wiadomo, żaden ze współczesnych autorów nie sądzi, że Jezus z Nazaretu czytał pisma greckie i z nich czerpał swą wiedzę.

Orygenes nie miał wątpliwości, że Maryja przyjęła orędzie anioła w duchu wiary i posłuszeństwa Bogu, podobnie uczynił Józef, przyjmując

57 Por. britannica.com/topic/synagogues: „Literature of the 1st century refers to numerous synagogues not only in Palestine but also in Rome, Greece, Egypt, Babylonia, and Asia Minor. By the middle of that century, all sizable Jewish communities had a synagogue where regular morning, afternoon, and evening services were held, with special liturgies on the Sabbath and on religious festivals [...]. The synagogue in which the community assembled became not merely a house of prayer but also a school with a house of book (bet ha-sefer) and a house of instruction (bet ha-midrash) corresponding to elementary and secondary levels of education".

58 Mello, Évangile, s. 267: „D’ailleurs Nazareth était une petite ville; nous ne sommes pas obligés de penser que Jésus soit entré dans édifice spécial [...]. C’était probablement une simple pièce spacieuse affectée à cet usage".

59 Por. J. Martin, Jezus, tł. K. Jasiński - A. Wawrzyniak, Poznań 2009, 100-101. Autor książki zaznacza, że druga część przytoczonego wyżej zdania pochodzi z następującego dzieła: J.P. Meier, Marginal Jew: Rethinking the Historical Jesus, t. 1, New York 1991, 274. Zob. R. Bartnicki, Działalność publiczna Jezusa Chrystusa, Warszawa 2011, 158-147. 
pouczenie we śnie jako głos Boga. Ale czy to oznacza pełne zrozumienie tajemnicy Jezusa i Jego dzieła? Zdaje się, że niezupełnie. Ewangelia mówi, że w czasie ofiarowania Jezusa w świątyni, gdy starzec Symeon wygłosił swe proroctwo o Jezusie, „Jego ojciec i Matka dziwili się temu, co o Nim mówiono" (Łk 2,33). Komentując to zdanie, Orygenes podkreśla, że słowo „ojciec", które jest tu użyte, nie oznacza rzeczywistego ojcostwa, lecz to, że „Duch Święty uczcił go tą nazwą, ponieważ Józef piastował Zbawiciela"60. Jest to zatem określenie honorowe. Orygenes dodaje: „Jego ojciec i Matka dziwili się temu, co o Nim mówił anioł, jak (dziwiło się) mnóstwo wojska

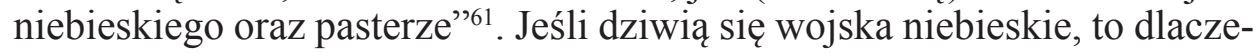
go nie mieliby się dziwić Maryja i Józef? To zdziwienie ze strony wielu istot ziemskich i niebieskich eksponuje wielkość tajemnicy, a pośrednio może oznaczać brak pełnego zrozumienia Bożych spraw, co wszakże nie stanowi zarzutu.

Trudności Maryi i Józefa zasygnalizowane są po raz drugi w związku z tym, jak dwunastoletni Jezus pozostał w gronie uczonych w Jerozolimie zamiast udać się w powrotną drogę do Nazaretu. Odnalazłszy Go, Maryja rzekła: „Synu, czemuś nam to uczynił, oto ojciec Twój i ja z bólem serca szukaliśmy Ciebie. Lecz On im odpowiedział: Czemuście Mnie szukali? Czy nie wiedzieliście, że powinienem być w tym, co należy do Mego Ojca? Oni jednak nie rozumieli tego, co im powiedział"62. Orygenes, komentując ten fragment Ewangelii, zaznacza: „Dziewica wiedziała, że to Dziecię nie było dzieckiem Józefa, jednakże uznała swego oblubieńca za ojca ze względu na podejrzenia Żydów, którzy sądzili, że Jezus urodził się w wyniku cudzołóstwa" ${ }^{63}$. Zapewne i Józef mówił o Jezusie jako swoim synu ${ }^{64}$. Następnie Orygenes pisze: „Zwróćcie uwagę i na to, że dopóki [Jezus] przebywał w posiadłości swego Ojca, znajdował się wysoko. A ponieważ Józef i Maryja nie posiadali jeszcze pełnej wiary, nie mogli przebywać z Nim na wysokości”65. To znaczy, że Józef i Maryja ufali

60 Origenes, In Lucam homiliae 17, 1 (PSP 36, 78).

61 Origenes, In Lucam homiliae 17, 1 (PSP 36, 78).

62 Łk 2,48-50.

63 Origenes, In Lucam homiliae, frag. 45/74 (PSP 36, 159). Orygenes dokonuje przeskoku historycznego - w rzeczywistości nikt nie miał wątpliwości, że Józef jest ojcem Jezusa, ani nikt nie podejrzewał Maryi o cudzołóstwo. Takie pogłoski zaczęto rozpowszechniać wiele lat po zmartwychwstaniu. Maryja posłużyła się słowem „ojciec” w stosunku do Józefa, gdyż tak go powszechnie określano.

64 Przedstawił to obrazowo: R. Brandstaetter, Jezus z Nazaretu, t. 1, Warszawa 1987, 126: „Józef, zaprowadziwszy Jezusa do szkoły, rzekł do nauczyciela (chazana): «to jest mój syn»".

65 Origenes, In Lucam homiliae 20, 4 (PSP 36, 88). 
Bogu, nawet jeśli w pełni nie rozumieli Jego planów. Orygenes pisze o Maryi: „Podejrzewała, że [Jezus] ma w sobie coś, co przekracza ludzką naturę; Dlatego też «chowała wszystkie Jego słowa w swym sercu» - nie jako słowa chłopca, który miał dwanaście lat, lecz jako słowa Tego, który się począł z Ducha Świętego"66. O tym, że Maryja miała świadomość, iż Jej misja jako Matki Jezusa jest wyjątkowa, świadczy to, co wypowiedziała do Elżbiety w Magnificat ${ }^{67}$. Ks. Marek Starowieyski, omawiając nauczanie Orygenesa, pisze, że „Maryja uznawała Jezusa za kogoś bardzo wielkiego, nie znaczy to jednak, że od początku uznawała Go za Boga" ${ }^{68}$. Wydaje się, że myślenie Józefa było podobne, chociaż można przypuszczać, że jego poznanie Jezusa mogło być mniejsze od tego, jakie posiadała Maryja. Nigdzie nie odnotowano, kiedy Józef zakończył życie na tym świecie ${ }^{69}$. Zapewne nie żył on wtedy, gdy Jezus rozpoczął publiczną działalność. Nie było go na uczcie weselnej w Kanie Galilejskiej, nie ma w Ewangeliach wzmianki o jego pogrzebie, nie było go ani pod krzyżem, ani w wieczerniku. Wiadomo, że Maryja pozostawała pośród żyjących znacznie dłużej, na pewno Jej wiedza została pogłębiona po zmartwychwstaniu Jezusa i po zesłaniu Ducha Świętego.

\subsection{Rodzina Józefa}

Gdy chodzi o pochodzenie św. Józefa, to są dwie genealogie, które różnią się od siebie: Mateusza $(1,16)$ i Łukasza $(3,25-38)$. Dostrzega się tam pomieszanie rodu Salomona i Natana. W obu genealogiach jest podane, że Józef pochodził z rodu Dawida i to jest najważniejsze ${ }^{70}$. Już w starożytności dyskutowano nad tą rozbieżnością. Sprawą zajął się rzymski chronograf Juliusz Afrykańczyk. Na jego dzieło powołał się słynny historyk Euzebiusz z Cezarei $(+339)$ :

66 Origenes, In Lucam homiliae 20, 6 (PSP 36, 89).

67 Por. J. Ratzinger - H.U. von Balthasar, Marie première Église, tł. R. Givord, Paris 1987, 46: „Le Magnificat montre combien elle-même vivait du cœur de cette tradition qui s'enracine dans la promesse faite à Abraham et à sa descendance et se manifeste sans cesse comme la grande action miséricordieuse de Dieu".

68 M. Starowieyski, Mariologia Orygenesa, w: Orygenes, Homilie o Ewangelii św. Łukasza, PSP 36, Warszawa 1986, 24.

69 Por. P. Grelot, Saint Joseph. Bible, DSAM VIII 1290: „Joseph est certainement mort avant que Jésus commence son ministère".

70 Por. J.B. Green, The Gospel of Luke, Cambridge 1997, 188-189: „Genealogies serve as indicators of inherited status [...] genealogies are concerned as much with theological and apologetic issues as with historical; in them resides remarkable social power". 
Imiona rodowe liczono w Izraelu na podstawie naturalnej albo prawnej. $\mathrm{Na}$ podstawie naturalnej wtenczas, kiedy następował syn rodzony, na podstawie zaś prawnej, kiedy brat spłodził dziecko, a dał mu imię brata zmarłego [...]. Tak więc żadna z dwóch Ewangelii nie mija się z prawdą, tylko raz liczy (podaje imię ojca) na podstawie naturalne, a drugi raz prawnej. Oba wywody dochodzą do Józefa, w sposób wprawdzie zawiły, ale poprawny ${ }^{71}$.

Dodajmy, że do różnych pomyłek przy kopiowaniu ksiąg, w tym zapisków rodowych, dochodziło w związku z niewolą babilońską (586-538).

Powyższy pogląd na różnicę w genealogii Mateusza i Łukasza przyjął się wśród autorów chrześcijańskich, zaakceptował go na przykład św. Augustyn (+430). Jednakże, nawet gdyby istniały rzeczywiste rozbieżności na liście genealogii, to nie miałyby one większego znaczenia dla wiary chrześcijańskiej. Trudniej przedstawiała się kwestia małżeństwa Józefa z Maryją - rodziły się pytania i róże domysły. Na przykład „Ebionici twierdzili, że Jezus narodził się z naturalnego związku Józefa i Maryi" "72. Cała tradycja chrześcijańska odrzuca taki pogląd. Wątpliwości budziło zdanie: „Józef uczynił tak, jak mu polecił anioł Pański: wziął swoją Małżonkę do siebie, lecz nie zbliżał się do Niej, aż porodziła Syna, któremu nadał imię Jezus" "73. Wyciągano z tego wniosek, że Józef i Maryja po urodzeniu Jezusa prowadzili życie małżeńskie. Taką myśl zdawała się wyrażać inna wypowiedź Ewangelisty: „Czy nie jest On synem cieśli? Czy Jego Matce nie jest na imię Mariam, a Jego braciom Jakub, Józef, Szymon i Juda? Także Jego siostry czy nie żyją wszystkie u nas?" 74 . Polski biblista ks. Józef Homerski pomija w swym komentarzu zagadnienie braci i sióstr Jezusa $^{75}$. Amerykański biblista Richard T. France uważa, że imiona braci zaczerpnięte są ze Starego Testamentu ${ }^{76}$, z czego wynika, że mają charakter symboliczny. Inny biblista współczesny William L. Lane w komentarzu do Ewangelii Marka, gdzie jest mowa o braciach i siostrach Jezusa, zupełnie pomija to zagadnienie ${ }^{77}$. W starożytności niektórzy sądzili, że wymienieni

71 Eusebius Caesarensis, Historia ecclesiastica I 7, 1, tł. A. Caba: Euzebiusz z Cezarei, Historia kościelna, ŹMT 70, Kraków 2013, 47.

72 Starowieyski, Mariologia Orygenesa, s. 14.

73 Mt 1,24.

74 Mt 13,54. Por. Mk 6,3.

75 Por. J. Homerski, Ewangelia św. Jana, Wstęp, przekład, komentarz, Warszawa 1979, 229.

76 Por. R.T. France, The Gospel of Matthew, Cambridge 2007, 550: „All four names are taken from patriarchs of Genesis".

77 Por. W.L. Lane, The Gospel of Mark. Introduction, Exposition and Notes, Grand Rapids - Cambridge 1974, 200-201. 
bracia mogli być rodzeństwem Jezusa w sensie ścisłym. Taki pogląd znany był Orygenesowi. Pisał on:

Pewien heretyk tak daleko posunął się swej głupocie, iż twierdził, jakoby Jezus wyparł się Maryi, ponieważ ona po urodzeniu Jezusa połączyła się z Józefem [...]. [Heretycy] głosząc, że Maryja zawarła małżeństwo po urodzeniu Jezusa, nie potrafią tego udowodnić. Ci bowiem, których nazywano synami Józefa, nie urodzili się z Maryi, a i żaden tekst Pisma o tym nie wspomina $^{78}$.

Zdaniem M. Starowieyskiego owym heretykiem był Marcjon ${ }^{79}$. Maryja formalnie zawarła małżeństwo z Józefem już wcześniej. W tym zdaniu Orygenes mówiąc, ,zawarła małżeństwo” (asserunt eam nupsisse), miał na myśli rozpoczęcie życia małżeńskiego w zwykłym tego słowa znaczeniu. W całej tradycji chrześcijańskiej nigdy nie przyjmowano takiej możliwości.

Niektórzy pisarze, chcąc wyjaśnić, w jakim sensie wymienieni przez Mateusza ludzie (Jakub, Józef, Szymon i Juda) są braćmi Jezusa, wysuwali hipotezę, że mogli to być synowie nie Maryi, lecz Józefa z pierwszego małżeństwa. Takie opinie rozpowszechniały pisma apokryficzne, jak Protowangelia Jakuba ${ }^{80}$ czy Ewangelia Pseudo-Mateusza ${ }^{81}$. Do tej kwestii nawiązał Orygenes w komentarzu do Ewangelii św. Mateusza:

Myśleli (niektórzy), że Jezus był synem Józefa i Maryi, natomiast sądzili,

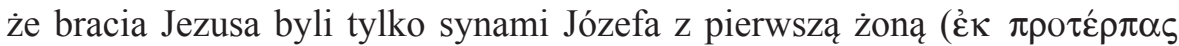
$\gamma(v \propto \imath \kappa o ̀ s)$, którą poślubił przed Maryją. Do takich doszli wniosków na podstawie tradycji zawartej w Ewangelii przypisywanej Piotrowi albo z księgi Jakuba. Ci, którzy tak mówią, pragną zachować dziewictwo Maryi aż do koń-

78 Origenes, In Lucam homiliae 7, 4 (PSP 36, 49).

79 Por. Starowieyski, Mariologia Orygenesa, s. 19; Orygenes, Homilie o Ewangelii św. Łukasza, s. 49, przyp. 5. Marcjon żył na przełomie I i II wieku, uważał się za chrześcijanina, ale w rzeczywistości głosił naukę zbliżoną do gnozy, nie uznawał Starego Testamentu. Zob. K. Bihlmeyer-H. Tüchle, Historia Kościoła, tł. J. Klenowski, Warszawa 1971, 159-160.

80 Por. Protoevangelium Iacobi IX 3, tł. M. Starowieyski: Apokryfy Nowego Testamentu, t. I/1, red. M. Starowieyski, Kraków 2005, 275: „Rzekł kapłan: Józefie, Józefie, na ciebie wypadło, abyś wziął dziewicę Pańską. I sprzeciwił się Józef i rzekł: Mam synów i jestem starcem".

${ }^{81}$ Por. Pseudo-Matthaei Evangelium 8, 4, tł. K. Obrycki, Apokryfy Nowego Testamentu, t. I/1, 304: „Józef zaczął błagać i prosić zapytując: Jestem stary i mam synów, dlaczego więc mnie powierzacie tę dzieweczkę?". 
ca, aby Jej ciało wybrane dla służenia Słowu [...] nie zaznało współżycia

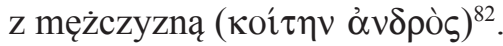

Orygenes, jak widać, znał pogląd o poprzednim małżeństwie Józefa, a nawet wiedział, że pochodził on z apokryficznej Ewangelii Piotra oraz z księgi Jakuba, czyli zapewne z Protoewangelii Jakuba. Rozumiał też motywację tych pisarzy, którzy sądzili, że owi bracia i siostry Jezusa mogli być dziećmi Józefa z pierwszego małżeństwa. Ci pisarze chcieli utrzymać przekonanie o dziewictwie Maryi zachowanym przez całe życie. Orygenes nie dopuszczał myśli o małżeńskim pożyciu Józefa i Maryi po narodzeniu Jezusa, nie podzielał poglądu o pierwszym małżeństwie Józefa, ale takiej możliwości nie wykluczał. W swych dziełach wszakże nie analizował szczegółowo tego zagadnienia.

Hilary z Poitiers $(+367)$, którego można traktować jako przedstawiciela teologii na Zachodzie, zdecydowanie wykluczał to, iż Maryja mogła mieć inne dzieci po narodzeniu Jezusa, ale dopuszczał myśl, że owi bracia Jezusa mogli być synami Józefa z pierwszego małżeństwa ${ }^{83}$. Cyryl Aleksandryjski $(+444)$, komentując wzmiankę o braciach Jezusa w Ewangelii Jana (7,3$5)^{84}$, wspomniał o opinii o pierwszym małżeństwie Józefa. Możliwe, że brał taką możliwość pod uwagę, idąc za wcześniejszą tradycją, ale - podobnie jak Orygenes - nie omawiał wprost tej kwestii, a chciał tylko podkreślić, że owi bracia nie byli synami Maryi. Dla autorów chrześcijańskich ważne było Jej dziewictwo zachowane przez całe życie. Pożycie małżeńskie Maryi z Józefem oraz pierwsze małżeństwo Józefa z inną kobietą wykluczał św. Hieronim $(+419)^{85}$, a także inni autorzy wczesnochrześcijańscy ${ }^{86}$.

82 Origenes, Commentarium in Evangelium Matthaei X 17 (tłum. własne).

83 Hilarius Pictaviensis, Commentarius in Matthaeum I 4, tł. E. Stanula: Święty Hilary z Poitiers, Komentarz do Ewangelii św. Mateusza. Traktat o Tajemnicach, PSP 63, Warszawa 2002, 45: „Ludzie przewrotni tym również umacniają autorytet swych błędnych przekonań, iż Pan miał wielu braci. Gdyby to byli synowie Maryi, a nie Józefa z pierwszego małżeństwa, nigdy by w czasie męki Maryja nie została oddana za matkę Janowi Apostołowi (por. J 19,26-27)".

${ }^{84}$ Por. Cyrillus Alexandrinus, In Joannis Evangelium IV 5: „[...] ne ipsi ex beata Virgine nati cencerentur, sed potius ex solo patri Joseph".

85 Hieronymus, De perpetua virginitate Beatae Mariae adversus Helvidium 19, tł. T. Kaczmarek: www.swietyjozef.kalisz.pl/BibliotekaSwJozefa/246.html (dostęp: 24.02.2019): „Skoro przyjmujemy to, co mówi Pismo, musimy odrzucić to, czego tam nie ma. [...] Moglibyśmy rozważać, że Józef miał więcej żon, z których narodzili się «bracia Pańscy». To jednak z pewnością jest tylko czystym domysłem [...]. Gdy chodzi o jego odniesienie do Maryi musimy patrzeć na niego raczej jako na jej opiekuna, a nie męża. Pozostaje przeto stwierdzić, że ten, który zasłużył na miano ojca Pana, przebywając z Maryją pozostał w stanie dziewictwa".

86 Por. Bertrand, Saint Joseph, k. 305: „Les Pères tiennent également à affirmer la chasteté complète de Joseph après la naissance du Christ”. 
Powyższe aluzje do kilku teologów wskazują, że niektóre opinie na temat Maryi i Józefa istniały tak w czasach Orygenesa, jak i znacznie później. Pogląd o pierwszym małżeństwie Józefa stopniowo tracił popularność na korzyść poglądu o czystości tak Maryi, jak i Józefa. Obecnie, zgodnie $\mathrm{z}$ tradycją orientalną, pod pojęciem braci Jezusa i Jego sióstr rozumie się członków rodziny w sensie szerszym, czyli osoby spokrewnione.

\section{Zakończenie}

Zasygnalizowaliśmy najważniejsze punkty nauki Orygenesa na temat św. Józefa. Dało się zauważyć, że teolog ten nie uprawiał tego, co dziś określilibyśmy mianem józefologii. Nie interesował się on wprost postacią Józefa, a wspominał o nim, gdy mówił o Chrystusie i Maryi, a szczególnie o dziewiczym poczęciu Jezusa. W centrum myśli teologicznej Orygenesa był zawsze boski Logos, który dla zbawienia ludzi przyjął ludzką naturę. Czynnikiem, który inspirował Orygenesa do pisania o Józefie, były satyryczne pogłoski rozsiewane przez wrogów chrześcijaństwa. Podczas gdy jedni głosili, że Jezus był synem Józefa, inni dowodzili, że został poczęty w nielegalnym związku Maryi z jakimś obcym mężczyzną pod nieobecność Józefa. By nadać waloru takim pogłoskom, wymyślono nawet imię tegoż mężczyzny (Pantera). Największym polemistą antychrześcijańskim był Celsus. Jeszcze inni, nie odrzucając wprost nauki o Bożym macierzyństwie Maryi, twierdzili, że po narodzeniu Jezusa Józef i Maryja prowadzili życie małżeńskie i że z tego związku urodzili się tak zwani bracia Jezusa i Jego siostry, o których jest mowa w Ewangeliach. W takich okolicznościach Orygenes podjął zdecydowaną polemikę z fałszywymi pogłoskami i komentował naukę zawarta w Ewangeliach na temat natury Jezusa Chrystusa, Maryi jako Jego matki oraz św. Józefa jako Jej małżonka, ale nie w potocznym tego słowa znaczeniu.

\section{Święty Józef jako opiekun Jezusa i małżonek Maryi według Orygenesa}

(streszczenie)

W niniejszym artykule autor podjął próbę przedstawienia postaci św. Józefa na podstawie pism Orygenesa. Dla lepszego ich zrozumienia należało sięgnąć do pism także innych autorów okresu patrystycznego oraz do opracowań teologów współczesnych. W pierwszym punkcie znajduje się wzmianka o znaczeniu nazwy miasta Nazaret. Nie wydaje się, aby miała ona wpływ na to, iż Józef i Maryja zamieszkali w tym mieście, niektórzy autorzy natomiast dopatrują się znaczenia symbolicznego we wszystkim, co dotyczy Jezusa, Maryi 
i Józefa. W drugim punkcie poruszona jest kwestia wątpliwości Józefa. Trzeci punkt dotyczy legendy o niejakim Panterze, który rzekomo miał być ojcem Jezusa. W czwartym rozdziale ukazana jest wyjątkowa rola św. Józefa jako małżonka Maryi oraz opiekuna Jezusa. Wartość niniejszego artykułu polega na tym, że ukazuje on ciągłość wiary chrześcijańskiej od czasów apostolskich, poprzez starożytność, aż do naszych czasów. Kościół w niczym nie odszedł od nauczania Ewangelii na temat Jezusa, Maryi i Józefa.

Słowa kluczowe: Jezus; Maryja; Józef; Orygenes; Nazaret; Betlejem; narodzenie; opiekun

\section{Saint Joseph as a Protector of Jesus and Husband of Mary according to Origen}

(summary)

The author of the article presented the most important points of Origen's teaching on Saint Joseph. It is to be noticed that there is no josephology in the contemporary sense of this term. As matter of fact, Origen was not interested in Joseph's person; he spoke about him while speaking about Christ and Mary, and about the Virginal conception of Jesus. In the center of Origen's thoughts was the Divine Logos who accepted the human nature for the people's salvation. Origen decided to write something on Joseph because of the satirical stories propagated by the enemies of Christianity; Celsus was the most famous among them. Some anti-Christian polemists proclaimed that Jesus was Joseph's son, some others said that He was conceived within an illegal union of Mary with a stranger; they invented his name (Panthera). There were people who declared that Joseph and Mary had had sexual relations after the birth of Jesus; the persons called brothers and sisters of Jesus were apparently born from such a union. In such circumstances Origen started to refute the false stories and to present the Gospel's teaching on Jesus Christ, on His Mother Mary and on Joseph. Origen underlined that Joseph was Mary's husband, but not in the common sense of this word.

Keywords: Jesus; Mary; Joseph; Origen; Nazareth; Bethlehem; nativity; protector

\section{Bibliografia}

\section{Teksty źródłowe}

Ambrosius, Expositio Evangelli secundum Lucam, red. C. Schenkl, Pragae - Vidobonae -Lipsiae 1902, tł. W. Szołdrski: Św. Ambroży, Wykład Ewangelii św. Lukasza, PSP 16, Warszawa 1977.

Caius Suetonius Tranquillus, De vita caesarum libri XII, red. M. Ihm, Lipsiae 1907, tł. J. Niemirska-Pliszczyńska: Gaius Swetoniusz Trankwillus, Żywoty cezarów, Warszawa 1969.

Cyrillus Alexandrinus, In Joannis Evangelium, PG 73, 17-704. 
Eusebius Caesarensis, Historia ecclesiastica, PG 20, 45-906, tł. A. Caba: Euzebiusz z Cezarei, Historia kościelna, ŹMT 70, Kraków 2013

Germanus, In sanctissimae Dei Genetricis Annuntiationem, PG 98, 320-339, tł. W. Kania: Teksty o Matce Bożej. Ojcowie greccy i syryjscy, t. 1, red. W. Kania, Niepokalanów 1981, 170-182.

Hieronymus, De perpetua virginitate Beatae Mariae adversus Helvidium, PL 23, 183-206. Hilarius Pictaviensis, Commentarius in Mathaeum, red. J. Doignon, SCh 254; 258, Paris 1978-1979, tł. E. Stanula, w: Święty Hilary z Poitiers, Komentarz do Ewangelii św. Mateusza. Traktat o Tajemnicach, PSP 63, Warszawa 2002, 43-200.

Hilarius Pictaviensis, Tractatus mysteriorum, red. J.-P. Brisson, SCh 19 bis, Paris 1967, tł. E. Stanula: Święty Hilary z Poitiers, Komentarz do Ewangelii św. Mateusza. Traktat o Tajemnicach, PSP 63, Warszawa 2002, 203-232.

Historia Iosephi fabri lignarii, tł. T. Hergesel, w: Apokryfy Nowego Testamentu, t. I/2, red. M. Starowieyski, Warszawa 2003, 559-578.

Origenes, Commentarium in Evangelium Matthaei, PG 13, 829-1800.

Origenes, Contra Celsum, red. M. Borret, SCh 132; 136; 147; 150; 227, Paris 1967-1977, tł. S. Kalinkowski: Orygenes, Przeciw Celsusowi, PSP 17, Warszawa 1986.

Origenes, Homiliae in Genesim, red. L. Doutreleau, SCh 7 bis, Paris 1956, t1. S. Kalinkowski: Orygenes, Homilie o Księgach Rodzaju, Wyjścia, Kapłańskiej, PSP 31/1, Warszawa 1984, 21-154.

Origenes, In Lucam homiliae, red. H. Crouzel - F. Fournier - P. Périchon, SCh 87, Paris 1962, tł. S. Kalinkowski: Orygenes, Homilie o Ewangelii św. Łukasza, PSP 36, Warszawa 1986.

Protoevangelium Iacobi, tł. M. Starowieyski: Apokryfy Nowego Testamentu, t. I/1, red. M. Starowieyski, Kraków 2005, 266-290.

Pseudo-Matthaei Evangelium, tł. K. Obrycki, w: Apokryfy Nowego Testamentu, t. I/1, red. M. Starowieyski, Kraków 2005, 293-316.

Tertullianus, Adversus Marcionem, red. A. Kroymann, CCL 1, Turnholti 1954, 437-726, tł. S. Ryznar: Tertulian, Przeciw Marcjonowi, PSP 57, Warszawa 1994.

\section{Opracowania}

Bartnicki R., Działalność publiczna Jezusa Chrystusa, Warszawa 2011.

Bartnicki R., Dzieje głoszenia Słowa Bożego. Jezus i najstarszy Kościót, Kraków 2015.

Benedykt XVI, Jezus z Nazaretu. Dzieciństwo, tł. W. Szymona, Kraków 2012.

Bertrand G.M., Saint Joseph époux de Marie. Patristique et haut Moyen Age, DSAM VIII 1301-1308.

Bihlmeyer K. - Tüchle H., Historia Kościoła, tł. J. Klenowski, Warszawa 1971.

Boureau A., La papesse Jeanne, Paris 1988.

Brandstaetter R., Jezus z Nazaretu, t. 1-2, Warszawa 1987.

Fédou M., Christianisme et religions païennes dans le Contre Celse d'Origène, Paris 1988. 
Fox R.L., Païens et chrétiens. La religion et la vie religieuse dans l'Empire Romain de la mort de Commode au Concile de Nicée, tł. R. Almi - M. Montabrut - E. Pailler, Toulouse 1997.

France R.T., The Gospel of Matthew, Cambridge 2007.

Fros H. - Sowa F., Twoje imię. Przewodnik onomastyczno-hagiograficzny, Kraków 1975. Gauthier R., Saint Joseph époux de Marie. L’histoire de la spiritualité, DSAM VIII 13081316.

Gauthier R., Saint Joseph époux de Marie. Liturgie et documents pontificaux, DSAM VIII 1316-1321.

Gnilka J., Das Matthäusevangelium, Erster Teil, Herders theologischer Kommentar zum Neuen Testament, t. I/1, Freiburg - Basel - Wien 1986.

Green J.B., The Gospel of Luke, Cambridge 1997.

Grelot P., Saint Joseph époux de Marie. Écriture, DSAM VIII 1289-1301.

Homerski J., Ewangelia św. Jana, Wstęp, przekład, komentarz, Warszawa 1979.

J.P. Meier, Marginal Jew: Rethinking the Historical Jesus, t. 1, New York 1991.

Kalinkowski S., Wstęp, w: Orygenes, Przeciw Celsusowi, tł. S. Kalinkowski, Warszawa 1986, 6-32.

Labriolle P. de, La réaction païenne. Étude sur la polémique antichrétienne du $I^{e r}$ au VI siècle, Paris 1950.

Lane W.T., The Gospel of Mark. Introduction, Exposition and Notes, Cambridge 1974.

Martin J., Jezus, tł. K. Jasiński - A. Wawrzyniak, Poznań 2009.

Mello A., Évangile selon Saint Matthieu, tł. A. Chevillon, Paris 1999.

Naumowicz J., Narodziny Bożego Narodzenia, Kraków 2016.

Ratzinger J. - Balthasar H.U. von, Marie première Église, tt. R. Givord, Paris 1987.

Reale G., Historia filozofii starożytnej, t1. E.I. Zieliński, t. 2, Lublin 1997.

Reboul M., L'immaculée Conception, Clé de la voûte de la Création, Versailles 2018.

Rustici C., The Afterlife of Pope Jean: Developing of the Popess Legend in Early Modern England, Michigan 2006.

Simon M. - Benoît A., Le Judaïsme et le Christianisme antique d'Antiochus Epiphan à Constanin, Paris 2006.

Solignac A., Saint Joseph époux de Marie. Le culte de saint Joseph aujourd'hui, DSAM VIII (1974) 1321-1323.

Starowieyski M., Barwny świat apokryfów, Poznań 2015.

Starowieyski M., Mariologia Orygenesa, w: Orygenes, Homilie o Ewangelii św. Łukasza, PSP 36, Warszawa 1986, 5-29.

Starowieyski M., Plotka, pogarda, oszczerstwo - pisarze chrześcijańscy o poganach, w: Pierwsi świadkowie, red. M. Starowieyski, BOK 10, Kraków 1998, 351-397.

Szymik S., Józef Oblubieniec, EK VIII 124-125.

Tatarkiewicz W., Historia filozofii, t. 1, Warszawa 1978.

Vidal M., Un Juif nommé Jésus. Une lecture de l'Évangile à la lumière de Torah, Paris 2000 . 